\title{
Is the Reproduction Capacity of Pinus brutia Stands 20 Years after Wildfire Efficient to Secure Forest Restoration in the Case of a Fire Re-Occurrence?
}

\author{
Petros Ganatsas*(D), Maria Giannakaki, Alexandros Gouvas and Marianthi Tsakaldimi $\mathbb{D}$ \\ Laboratory of Silviculture, Department of Forestry and Natural Environment, Aristotle University of \\ Thessaloniki, P.O. Box 262, 54124 Thessaloniki, Greece; mariagiann5@gmail.com (M.G.); \\ alex.gkouvas@gmail.com (A.G.); marian@for.auth.gr (M.T.) \\ * Correspondence: pgana@for.auth.gr
}

Citation: Ganatsas, P.; Giannakaki, M.; Gouvas, A.; Tsakaldimi, M. Is the Reproduction Capacity of Pinus brutia Stands 20 Years after Wildfire Efficient to Secure Forest Restoration in the Case of a Fire Re-Occurrence? Forests 2021, 12, 991. https://doi.org/ 10.3390/f12080991

Academic Editor: Costantino Sirca

Received: 21 June 2021

Accepted: 19 July 2021

Published: 26 July 2021

Publisher's Note: MDPI stays neutral with regard to jurisdictional claims in published maps and institutional affiliations.

Copyright: (c) 2021 by the authors. Licensee MDPI, Basel, Switzerland. This article is an open access article distributed under the terms and conditions of the Creative Commons Attribution (CC BY) license (https:/ / creativecommons.org/licenses/by/ $4.0 /)$.

\begin{abstract}
A critical issue in effective post-fire regeneration and re-establishment of a burnt forest is the stage concerning the burned stands. When stands are mature and produce seeds, the regeneration can theoretically be achieved, while in the case of immature stands, they may not be able to produce enough quantities of germinable seeds that can secure stand re-establishment. It is estimated that a period of 15-16 years after fire is needed for enough seed production to achieve natural forest re-establishment. This study aimed at the estimation of the real reproduction capacity of Pinus brutia stands 20 years after a wildfire, in an area of northern Greece. The study focused on stand structure, cone production and their morphological characteristics, the morphological characteristics of the produced seed as well as quality of produced seeds. Results analyses showed that despite the young age of the stands, they are quite productive, producing a high number of cones per ha, with a high percentage of trees bearing cones, but with a low number of cones per tree (11.0 cones). An average number of 58.0 fully developed seeds per cone were found, which corresponds to a total number of 620,136 seeds per ha. Considering that the average rate of seed germination is $25.6 \%$ (at laboratory conditions), and the theoretical possibility for establishing viable seedling under ambient conditions, these data give an estimation of 1587.5 of one-year old seedlings to recruit the burnt area, in the case of a fire event, if all other parameters remain favorable. These data confirmed the hypothesis that a period of 15-16 years interval between two fires is enough for a burnt serotinous pine forest to reach in such a reproductive stage, able to secure its renewal if a fire occurs. This should be greatly considered in forest fire protection and management plans, which should aim to effectively protect young post-fire forests at least to the age of 15-16 years.
\end{abstract}

Keywords: repeated wildfires; post-fire forest regeneration; Turkish pine; cone yield

\section{Introduction}

Forest fires are a common phenomenon worldwide, and their frequency is expected to increase due to climate change [1,2]. They usually occur in forest ecosystems which are adapted to fires [3], such as the Mediterranean pines Pinus halepensis Miller and Pinus brutia Ten. These pine species have developed effective mechanisms for post-fire natural regeneration, thus, forest re-establishment after fire usually occurs naturally [4,5]. However, post-fire forest re-establishment for these types of ecosystems is not always secured, e.g., in the case of repeated fires, or under high inclination slopes [6].

A critical issue in effective post-fire regeneration and re-establishment of the burnt forest is the stage being the burned stands. If the stands are mature and produce seeds, the regeneration can be achieved (for the species adapted to wildfires such as P. brutia), while in the case of immature stands, they most likely are not able to produce enough quantities of germinated seeds that can secure stand re-establishment. This immaturity risk period depends on the amount of seeds stored in the canopy seed bank and the quantity of 
viable seeds available after a fire event. Post-fire regeneration of these species is exclusively related to the quality and quantity of the canopy seed bank, since soil seed banks have a transient character $[7,8]$.

It is generally estimated that a period of 15-16 years after fire is needed for a high seed production enough for natural forest re-establishment, for several fire-adapted species such as Banksia species in Australia [9], or pine species in Europe [7,10] and Asia [11]. This seed production was found to be affected by tree species and the local site conditions [10]. Tree early flowering is an important adaptation to wildfire: the sooner seed production starts, the sooner a large canopy seed bank is formed [10]. Even though, a period of 15-16 years after fire, is generally accepted for the species P. halepensis and P. brutia natural re-establishment, for the last species, there are no data concerning cone production and seed yield in relation to stand age, especially, under post-fire conditions. Some studies have shown that there are serotinous pine species, such as P. halepensis and P. pinaster Aiton, that start an early flowering, even at the age of 4-5 years, while there are other pines, non-serotinous, such as $P$. pinea L. and P. nigra Arnold, that do not produce a significant amount of seeds until the age of 15 years.

P. brutia is also an important Mediterranean serotinous pine species distributed in the east Mediterranean region [12] that greatly suffers from forest fires [13]. Similar to other serotinous pines, it starts an early flowering at the age of 4-6 years [14], but despite the observed early flowering, Kavgaci et al. [15] reported no natural regeneration in P. brutia stands that were still young when they burned. Additionally, there is a scarcity of available data concerning species cone and seed yield at different ages [12], especially under post-fire conditions, and the crucial time that it is needed to secure stand natural re-establishment after a fire [16].

The aim of this study was the estimation of the reproduction capacity of P. brutia stands 20 years after a wildfire, in an area of northern Greece, close to Thessaloniki city. The study focused on stand structure, cone production and their morphological characteristics, the morphological characteristics of the produced seed as well as the quality of seeds. Finally, an estimation of seedlings recruitment in the case of a fire re-occurrence is predicted.

\section{Materials and Methods}

\subsection{Study Area}

The study was carried out in the area of peri-urban forest of Thessaloniki, northern Greece (geographical coordinates 40.6282 N, 23.0095 E, Figure 1). The forest is originated from re-forestations, consisting mainly of the tree species P. brutia [17]. The forest occupies an area of ca 3000 ha, from which approximately 60\% was completely burnt in 1997 from a destructive forest fire event. The fire occurred on Sunday, 6 July 1997, 15:35, in the noon $\left(39^{\circ} \mathrm{C}\right)$. It spread quickly and completely burned more than half of the forest area over the two-days duration. After the wildfire, tree logging and grazing protection measures were applied in the whole burned forest area. The area consists of hilly formations, dominated by generally south aspects of low altitude, which ranges between $100 \mathrm{~m}$ to $560 \mathrm{~m}$ asl. The slope inclination ranges from $15 \%$ to $50 \%$. According to meteorological data (for the period 1946-2007) from the meteorological station of the Aristotle University of Thessaloniki, located at an altitude of $40 \mathrm{~m}$ in the center of the city, and in a distance of 5-15 km from the study area, the climate of the area belongs to the Csa category, which means "Typical Mediterranean climate with dry and hot summer", according to the Köppen classification. The mean annual precipitation is $449.3 \mathrm{~mm}$ and the mean annual temperature is $15.9^{\circ} \mathrm{C}$. The vegetation of the area belongs to the Mediterranean vegetation zone Quercetalia pubescentis, and specifically to the sub-zone Ostryo-Carpinion and the association Coccifero Carpinetum [6,17].

After the destructive fire, approximately half of the burnt area was planted with several forest species, while the remaining burnt area was left to naturally regenerate. Among the planted species, there were many broadleaved species used in order to convert the existing pro-fire pure pine stands into mixed stands. However, most of the planted 
seedlings did not manage to survive [17], mainly due to the absolutely lucking of any post-planting care (watering, weeding, etc.). Thus, the vegetation composition in the burnt area after the fire was dominated again by P. brutia, which in most locations recruited naturally the burnt area. Today, P. brutia dominates both the un-burnt and burnt areas and comprises the stand overstory. Locally, there is an abundant understory of shrub species, the most common being: Quercus coccifera, Phillyrea latifolia, Paliurus spina-christi, and Cistus creticus, whereas in some cases (best site qualities) the species Crataegus monogyna, Fraxinus ornus, and Ulmus campestris appear [6,17].

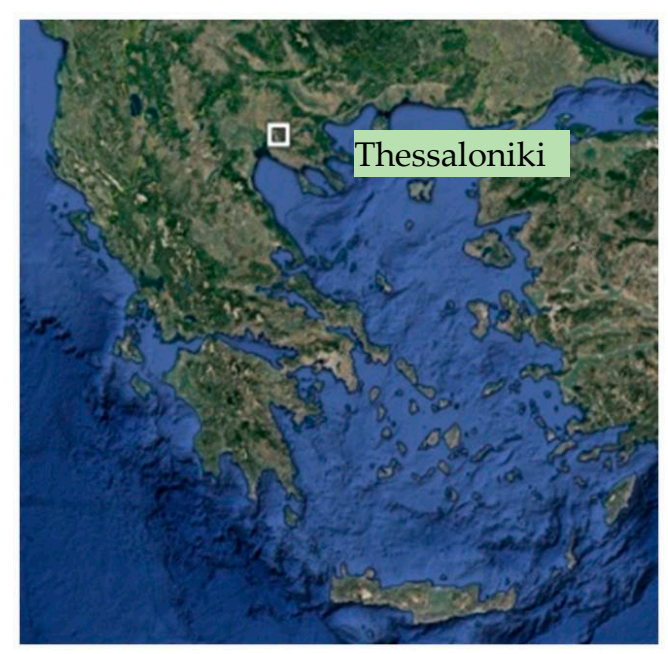

Figure 1. Map showing the study area, the peri-urban forest of Thessaloniki, northern Greece.

\subsection{Methods}

\subsubsection{Collection of Stand Structural Data}

A field campaign was carried out in the burnt forest 20 years after the fire, in May 2017, for field data collection. A total number of 30 plots were sampled, distributed in 3 different locations, (i) Toumpa, in the lower southern part of the forest, close to the city of Thessaloniki, (ii) Panorama, in the higher altitude of the forest, and (iii) Filippio in the western part of the forest, the most degraded part of the forest. Sampling was designed in such a way to cover as much as possible forest variability, and avoiding any effect of unburned forest stands, grazing pressure and phytosociological differentiations. In each plot (dimensioned $100 \mathrm{~m}^{2}-10 \mathrm{~m} \times 10 \mathrm{~m}$ [6], all the P. brutia trees were measured for their morphological characteristics, named diameter at breast height (DBH), in accuracy of $0.5 \mathrm{~cm}$, and total height, in accuracy of $10 \mathrm{~cm}$. Furthermore, a visual estimation of canopy cover was carried out.

\subsubsection{Cone Production and Morphological Characteristics}

In all trees, the number of cones per tree was visually measured, by starting from the down part of the slope and moving cycling around the tree. To confirm the cone record, the measurements were made by two experts. Due to the low number of cones per tree (average 11 , and less than 30 in all cases) and the low dimensions of the tress, no differences were prevailed between the two measurements in all cases. Afterwards, a number of 10 mature, closed cones per plot were randomly and manually collected (see Figure 2), with a total of 100 cones per location ( 300 cones totally). All cones were put on closed sealed bags, and transported to the laboratory for their measurements, and to a heat-induced opening for seed extraction [14]. Cone fresh weight was immediately measured (on the same day). Then, 30 cones per location were measured for their length and width. Afterwards, the cones were oven-dried in $72{ }^{\circ} \mathrm{C}$ for 3 days, and the cone dry weight was determined. 

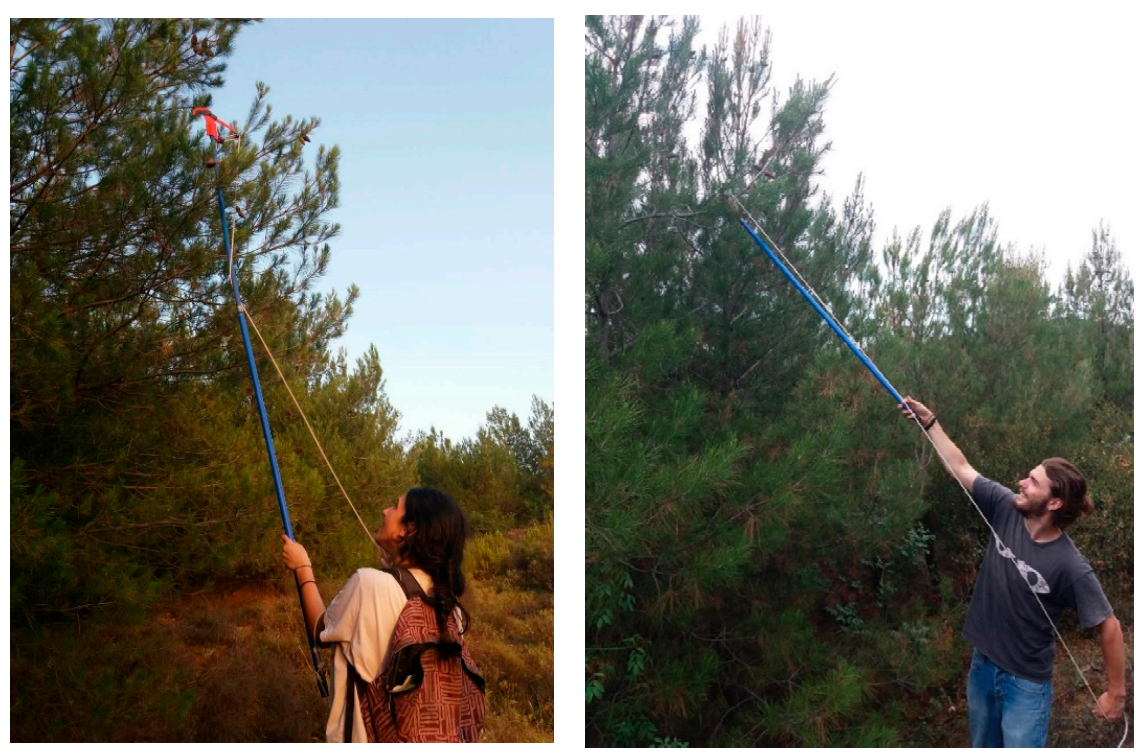

Figure 2. Cone collection in the field.

\subsubsection{Seed Measurements}

For each of the dried cones ( 90 cones totally), all the contained seeds were manually and carefully extracted after cone opening. The number of seeds per cone was measured. Seeds were separated as either fully developed, abnormal, or not fully developed. Then, 30 seeds per location were randomly selected (90 seeds totally). Their length, width, and dry weight was measured with a vernier caliper, and in precise balance, respectively. Additionally, in order to estimate the investment on seeds [18], the total seed weight per cone was computed as percentage of the total cone weight.

\subsubsection{Seed Germination Trial}

Four replications of 25 seeds per location were randomly selected for seed germination test. Seeds were placed on two filter paper discs in a 9-cm diameter Petri dish, and then covered with another filter paper disc [19]. The experiments were carried out in a temperature-controlled growth chamber at $20 \pm 0.5^{\circ} \mathrm{C}$ with a photoperiod of $12 \mathrm{~h}$ and luminance of 1000 lux [20]. Seeds were watered, as needed to provide seeds with an adequate moisture level [21], with distilled water. Every second day the seeds were checked for germination and fungus infection for 45 days duration. Every third day the filter papers were changed in order to avoid fungal infection. Seeds were considered to be germinated when the radical had double the size of the seed diameter. Seeds that had germinated but had been infected by fungus were recorded and removed in order to avoid further contamination. In addition, the filter papers were sprayed with fungicide at every change, before placing them in the Petri dishes.

\subsubsection{Statistical Analysis}

All data collected we subjected to statistical analysis performed by the SPSS software (version 23.0, SPSS Inc., Chicago, IL, USA). The percentage values of seed germination were arcsine-transformed to cover the normality and homogeneity assumptions [21]. One-way ANOVA was used to test significant differences of the seeds between the three locations. All statistical analyses were conducted using a critical significance level, $p$ value $\leq 0.05$, where otherwise is not indicated.

\section{Results}

\subsection{Stand Characteristics}

The stands are young pure stands, dominated exclusively by P. brutia trees of the same age, since they are coming from post-fire regeneration. They are 19 years old and present 
an even-aged structure in all 3 locations. Tree DBH and height distribution in the three locations (Figure 3), indicates a general similar tree distribution, with no great differences in tree morphological characteristics (Table 1). The mean stand density is generally low (1259.2 trees per ha), considering its young age (19 years) and the fact that stand density decreases with the increasing age. All stands are in the pole stage [22], presenting an average height of $3.59 \mathrm{~m}$, and $8.5 \mathrm{~cm}$ diameter at breast height.

Histogram DBH

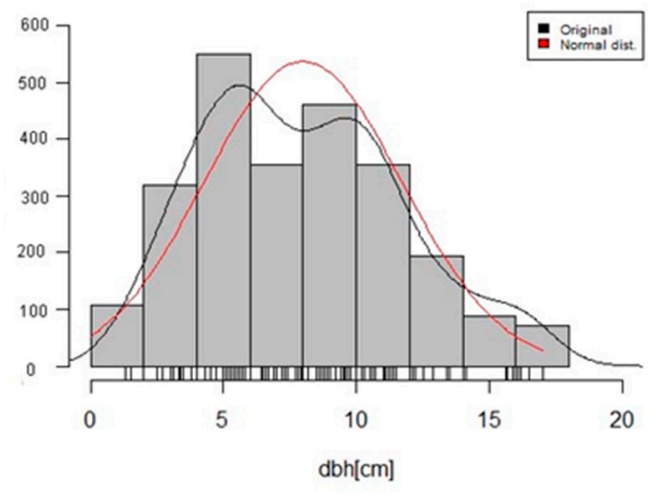

Histogram DBH

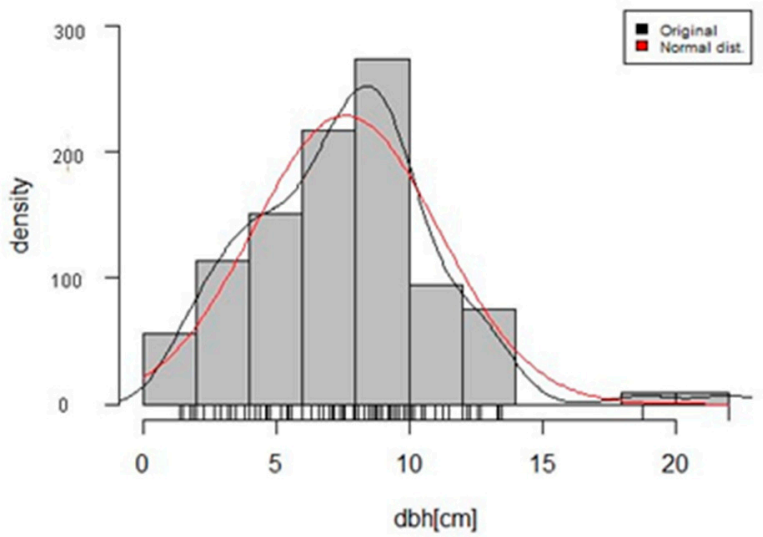

Histogram DBH

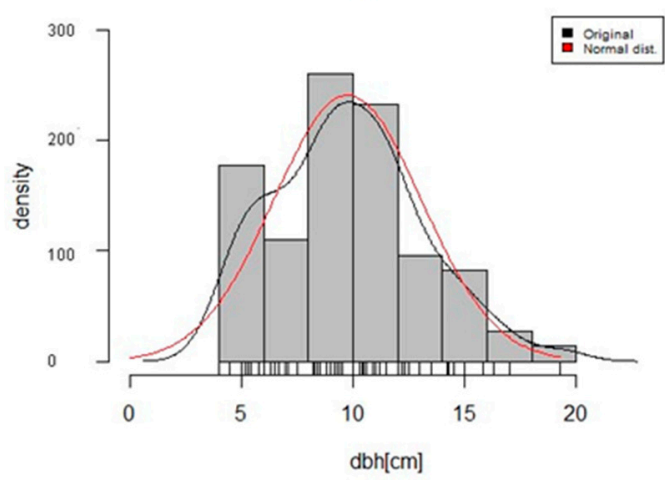

Histogram Height

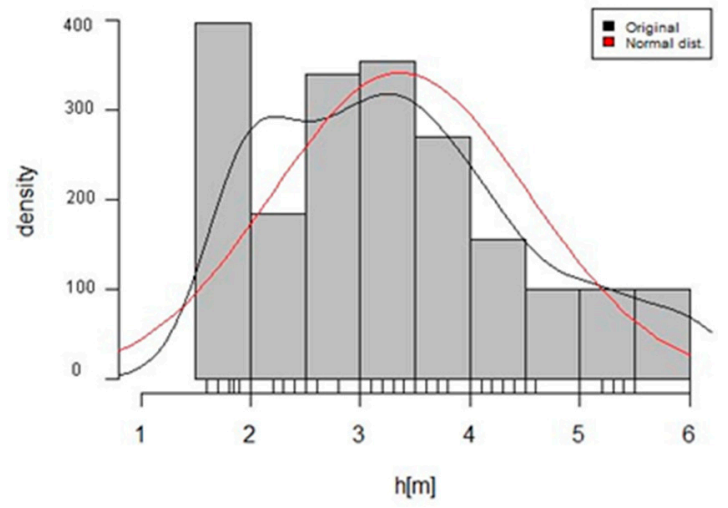

(a)

Histogram Height

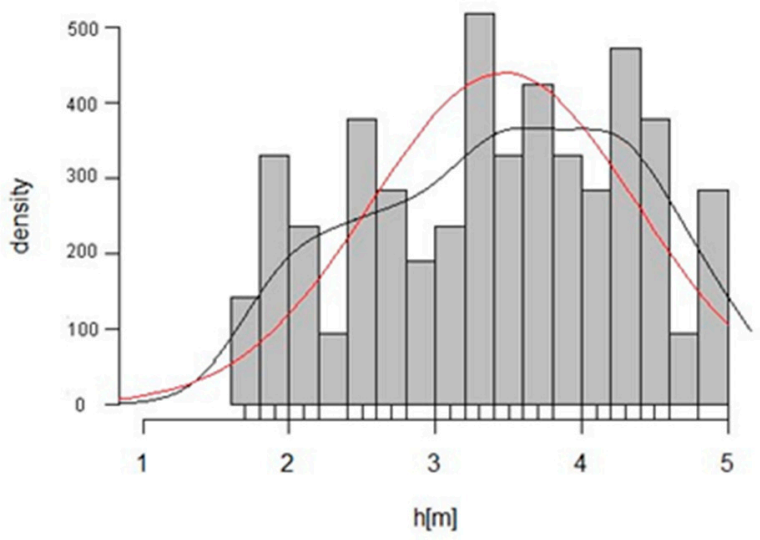

(b)

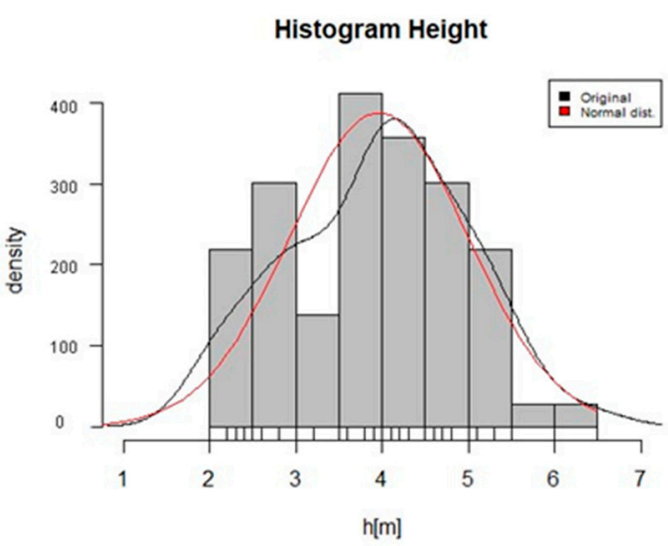

(c)

Figure 3. Tree DBH and height distribution in the three locations, 20 years after the fire. (a) Toumpa, (b) Panorama, (c) Filippio. 
Table 1. Structural characteristics of the studied P. brutia stands. Values are means and standard error of mean (in parenthesis).

\begin{tabular}{ccccc}
\hline Location & $\begin{array}{c}\text { Tree DBH } \\
\mathbf{c m}\end{array}$ & $\begin{array}{c}\text { Tree } \mathbf{H} \\
\mathbf{~}\end{array}$ & N/ha & $\begin{array}{c}\text { Tree Canopy Cover } \\
\mathbf{( \% )}\end{array}$ \\
\hline Toumpa & $8.0(0.0983)$ & $3.34(0.312)$ & 1410.0 & 65.3 \\
Panorama & $7.63(0.3381)$ & $3.47(0.088)$ & 1325.0 & 68.4 \\
Filippio & $9.76(0.3867)$ & $3.96(0.106)$ & 1042.8 & 70.1 \\
\hline Average & $8.5(0.1812)$ & $3.59(0.144)$ & 1259.2 & 67.9 \\
\hline
\end{tabular}

\subsection{Cone Yield}

A great percentage of $P$. brutia trees were found to bear cones-972 trees per hawhich corresponds to an average of $81.6 \%$ of the total number of trees (Table 2 ). Tree cone production per tree was found to be low, ranging between 6 and 15 cones, with an average value of 11.0 cones per tree. This results in an average number of 10,692 cones per ha. The number of cones per tree was found to be negatively correlated with stand density $(p=0.036, r=-0.67)$. On the contrary, the total number of cones per ha was found to be relatively stable, and not correlated with stand density. Similarly, the percentage of trees bearing cones was not correlated with stand density.

Table 2. Stand cone production of the studied P. brutia forest.

\begin{tabular}{ccccc}
\hline Location & $\begin{array}{c}\text { Number of } \\
\text { Trees with } \\
\text { Cones per ha }\end{array}$ & $\begin{array}{c}\text { Percentage of } \\
\text { Trees Bearing } \\
\text { Cones (\%) }\end{array}$ & $\begin{array}{c}\text { Mean Number } \\
\text { of Cones per } \\
\text { Tree }\end{array}$ & $\begin{array}{c}\text { Total Number } \\
\text { of Cones per ha }\end{array}$ \\
\hline Toumpa & 1060.0 & 84.0 & 15.0 & 15,900 \\
Panorama & 875.0 & 68.0 & 6.0 & 5250 \\
Filippio & 957.0 & 93.0 & 12.0 & 11,484 \\
\hline Mean & 972.0 & 81.6 & 11.0 & 10,692 \\
\hline
\end{tabular}

\subsection{Cone Characteristics}

Cone size ranged between 6.05 and $6.60 \mathrm{~cm}$ in length, and between 2.70 and $3.05 \mathrm{~cm}$ in width, while the average cone dry weight was $26.14 \mathrm{~g}$ (Table 3). Each cone contains an average number of 58.0 normal seeds, and 6 abnormal or not-fully developed seeds. The number of normal seeds per cone was found to be positively correlated with cone dimensions (Table 4) — the bigger the cones, the higher the number of seeds. Similarly, the number of abnormal seeds was negatively correlated with cone size. On the contrary, seed number per cone was found to not be correlated with either stand density or tree size.

Table 3. Cone characteristics of the studied P. brutia stands.

\begin{tabular}{|c|c|c|c|c|c|c|c|}
\hline \multirow{2}{*}{ Location } & \multirow{2}{*}{$\begin{array}{c}\text { Dry } \\
\text { Weight g }\end{array}$} & \multirow{2}{*}{$\begin{array}{c}\text { Water } \\
\text { Content \% }\end{array}$} & \multicolumn{2}{|c|}{ Cone Size } & \multirow{2}{*}{$\begin{array}{l}\text { N of Normal } \\
\text { Seeds }\end{array}$} & \multirow{2}{*}{$\begin{array}{l}\text { Nof Abnormal } \\
\text { Seeds }\end{array}$} & \multirow{2}{*}{$\begin{array}{c}\text { Percentage of } \\
\text { Abnormal Seeds \% }\end{array}$} \\
\hline & & & Length $\mathrm{cm}$ & Width cm & & & \\
\hline Toumpa & 28.021 & 16.0 & 6.60 & 3.05 & 57.0 & 9.0 & 10.14 \\
\hline Panorama & 25.690 & 18.4 & 6.05 & 2.71 & 52.0 & 7.0 & 14.13 \\
\hline Filippio & 27.712 & 15.8 & 6.40 & 2.81 & 65.0 & 2.0 & 3.14 \\
\hline Average & 26.141 & 16.7 & 6.35 & 2.87 & 58.0 & 6.0 & 9.13 \\
\hline
\end{tabular}


Table 4. Statistics between cone characteristics and containing seeds.

\begin{tabular}{|c|c|c|c|c|c|}
\hline & Cone Length & Cone Width & Fully Developed Seeds & Atrophic Seeds & Total Seeds \\
\hline \multicolumn{6}{|l|}{ Cone length } \\
\hline Pearson correlation & 1 & $0.821^{* *}$ & $0.528 * *$ & 0.302 & $0.561590 * *$ \\
\hline Sig (2-tailed) & & 0.000 & 0.006 & 0.134 & 0.000283 \\
\hline $\mathrm{N}$ & 26 & 26 & 26 & 26 & 26 \\
\hline \multicolumn{6}{|l|}{ Cone width } \\
\hline Pearson correlation & $0.821^{* *}$ & 1 & $0.548^{* *}$ & 0.295 & $0.580449 * *$ \\
\hline Sig (2-tailed) & 0.000 & & 0.004 & 0.144 & 0.001879 \\
\hline $\mathrm{N}$ & 26 & 26 & 26 & 26 & 26 \\
\hline \multicolumn{6}{|l|}{ Fully developed seeds } \\
\hline Pearson correlation & $0.528^{* *}$ & $0.548^{* *}$ & 1 & -0.151 & $0.995795^{* * *}$ \\
\hline Sig (2-tailed) & 0.006 & 0.004 & & 0.462 & 0.000000 \\
\hline $\mathrm{N}$ & 26 & 26 & 26 & 26 & 26 \\
\hline \multicolumn{6}{|l|}{ Atrophic seeds } \\
\hline Pearson correlation & 0.302 & 0.295 & -0.151 & 1 & -0.059438 \\
\hline Sig (2-tailed) & 0.134 & 0.144 & 0.462 & & 0.773 \\
\hline $\mathrm{N}$ & 26 & 26 & 26 & 26 & 26 \\
\hline \multicolumn{6}{|l|}{ Total seeds } \\
\hline Pearson correlation & $0.561590 * *$ & $0.580449 * *$ & $0.995795^{* * *}$ & -0.059438 & 1 \\
\hline Sig (2-tailed) & 0.000283 & 0.001879 & 0.000000 & 0.773 & \\
\hline $\mathrm{N}$ & 26 & 26 & 26 & 26 & 26 \\
\hline
\end{tabular}

** Correlation is significant at the 0.01 level (2-tailed), ${ }^{* * *}$ significant at the 0.001 level.

\subsection{Seed Morphological Characteristics}

Seeds of P. brutia presented an average length of $6.995 \mathrm{~mm}$ and $4.39 \mathrm{~mm}$ in width (Table 5). While their mean dry weight was found to be $30.21 \mathrm{mg}$, which corresponds to an average of 33,104 seeds per kg. Investment in seed mass as the ratio of seed mass per cone to total cone weight [18] reached an average value of $6.51 \%$, and it was found to be significantly higher in the case of Filippio stands.

Table 5. Seed morphological characteristics. Values followed by different letters are significantly different.

\begin{tabular}{cccccc}
\hline Location & $\begin{array}{c}\text { Seed Length } \\
\mathbf{m m}\end{array}$ & $\begin{array}{c}\text { Seed Width } \\
\mathbf{~ m m}\end{array}$ & $\begin{array}{c}\text { Width/Length } \\
\text { Ratio }\end{array}$ & $\begin{array}{c}\text { Seed Weight } \\
\text { mg }\end{array}$ & $\begin{array}{c}\text { Investment in } \\
\text { Seed Mass (\%) * }\end{array}$ \\
\hline Toumpa & $7.23 \mathrm{a}$ & $4.55 \mathrm{a}$ & 0.63 & $31.122 \mathrm{a}$ & $6.35 \% \mathrm{~b}$ \\
Panorama & $6.92 \mathrm{ab}$ & $4.37 \mathrm{ab}$ & 0.63 & $30.296 \mathrm{~b}$ & $6.13 \% \mathrm{~b}$ \\
Filippio & $6.83 \mathrm{~b}$ & $4.25 \mathrm{~b}$ & 0.62 & $30.011 \mathrm{~b}$ & $7.04 \mathrm{a}$ \\
\hline Mean & 7.00 & 4.39 & 0.63 & 30.207 & 6.51 \\
\hline
\end{tabular}

${ }^{*}$ ratio of seed mass per cone to total cone weight.

\subsection{Seed Germination}

Seed germination of the seedlings collected from the stands was low and did not differ between the three locations (Figure 4). The germination ranged between $24.0 \%$ and $28.9 \%$, with an average value of $25.6 \%$. Germination started on the 10 th day after sowing, and it was completed on the 26th day. After that day, no further seed germination was observed. 


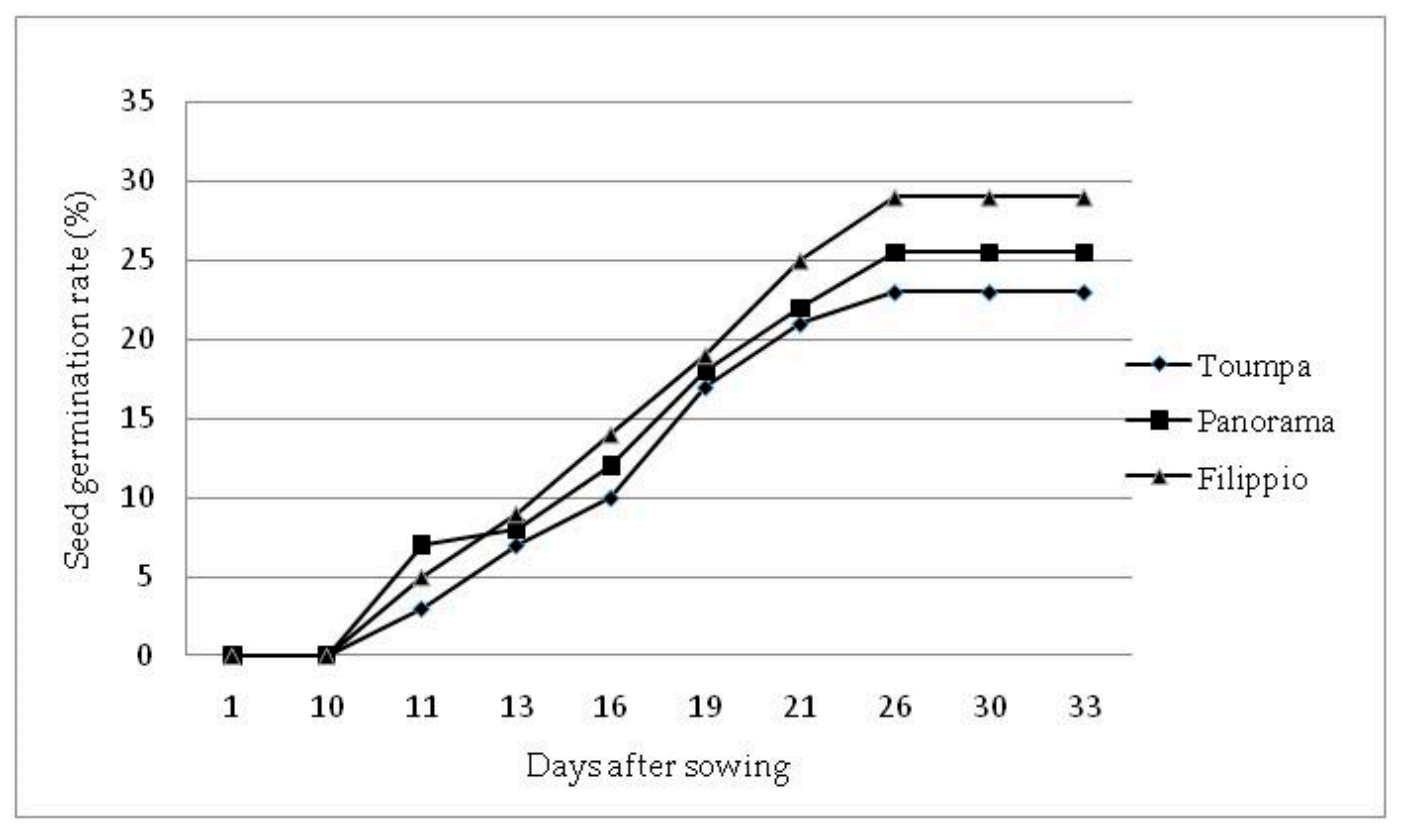

Figure 4. Accumulative curve of germination rates of Pinus brutia seeds at laboratory conditions.

\subsection{Estimation of Pinus brutia Stands Reproductive Capacity}

Data collected indicated that the P. brutia stands produce an average number of 10,692 cones per ha, at the age of 19 years, and 20 years after wildfire, was distributed at 972 trees per ha. Considering the time needed for the cones to mature (3 years), these values in fact represent the reproductive ability of the stands at the age of 16 years (flowering year). The average number of fully developed seeds were found to be 58.0 seeds per cone, which means that at stand level the number of seeds produced is 620,136 seeds per ha. If we consider that seeds present an average germination of $25.6 \%$ in laboratory conditions, this results in a number of 158,754 germinable seeds, 20 years after the fire. However, it has been suggested, based on several models on different tree species that approximately only $1 \%$ of available seeds have the possibility to germinate at field conditions and to produce a seedling, which means that seedling emergence in the field is strongly dependent on the quantity of seeds produced [23]. Thus, we can conclude that the average number of seedlings at ambient conditions can reach a number of 1587.5 of 1-year old seedlings per hectare, in the case of a fire event, when all other environmental parameters remain favorable for forest regeneration.

\section{Discussion}

Results analyses showed that the studied P. brutia stands, in an area closed to Thessaloniki city, northern Greece, established after a wildfire event that occurred 20 years before, are even-aged, in the pole stage [22], with a relatively low stem density and tree canopy cover (average values 1259.2 trees per ha and $67.9 \%$, respectively). This stem density is not surprising, given that the overall trend in forest stand development is a gradual decrease of pine sapling density during the 5-20 years after fire [6]. Spanos et al. [14], reported an average of sapling density ranging from 4000 to 10,000 stems per ha at the age of 9 years after fire for P. brutia stands on Thasos island, northern Greece. These reported density values were much higher than those of P. brutia for Samos island [24], but strikingly comparable to the P. halepensis ones of Mt Parnes [25]. However, it was reported that similar to Samos island [13], a regression analysis, with nicely fitted negative exponential curves obtained in both areas; the asymptotic level of survival was 20 and $40 \%$, respectively, of the seedlings established during the first post-fire spring. Stand density and tree distribution does not present great differences along the study area as it was expected [26], since unlike fire-free regeneration tree stands, in which multiple factors are 
likely to be important, post-fire regeneration is governed by fairly specific environmental factors (e.g., the chemical properties of ash) operating during a specific stage (seedlings or saplings) and at a specific location (the canopy projection of large burned pines), and thus, post-fire stands are therefore even-aged with predictable and quite similar spatiotemporal dynamics $[16,26]$.

Similar to other fire resilient pines [27], P. brutia is characterized by the production of a high number of serotinous cones, small seeds, and early reproduction capability. Thus, despite the young age of the studied P. brutia stands, these are quite productive and produce an average number of 10,692 cones per ha, at the age of 19 years. Considering the time needed for the cones to mature (3 years), these values in fact represent the reproductive ability of the stands at the age of 16 years (flowering year). The number of trees bearing cones is also high, at 972 trees per ha, while in contrast the number of cones per tree is very low (11.0 cones). Ganatsas and Thanasis [28] reported an average number of 810 cones per tree for $P$. halepensis mature stands (a genetically closed-related species to the studied species, for which some authors consider that both species are subspecies of the same species (e.g., Strid and Tan 1997, in Flora Hellenica vol 1 [29]), which results in a supply of 2 million seeds per hectare. Even though these measurements do not concern the same species, but a very closed genetically one, we can conclude that yield cone greatly depends on tree age, and it increases with tree age. The number of cones per tree was found to be negatively correlated with stand density; an increase in the number of trees per ha decreases the number of cones produced by a tree. This affects the cone yield at stand level, resulting in a similar number of cones per ha regardless of the stand density. Similarly, the percentage of trees bearing cones was not correlated with stand density.

An average number of 58.0 fully developed seeds per cone was found, which is much higher than that reported for 9-year-old P. brutia stands in Thasos (39.5 seeds per cone [13], but are similar to that reported [25] for young $P$. halepensis stands (aged 15-16 years) (average 59.5 seeds per cone), and slightly higher than that reported [28] for mature P. halepensis trees (average 52.8 seeds per cone). The produced yield of the current studied stands corresponds to a total number of 620,136 seeds ha ${ }^{-1}$, which is less than $1 / 3$ of that reported [28] for P. halepensis mature stands in southern Greece. While Tapias et al. [10], for conditions in Spain, reported that 15-16 years after the fire, P. halepensis stands had developed a canopy seed bank with 30,000-1,000,000 seeds ha ${ }^{-1}$, depending on the sites and the stand density. However, we must mention that in the last study the stand density was much higher (3000-11,000 trees per ha) compared to the P. brutia stand density of this study (1259.2 trees per ha). Considering the average rate of seed germination, which was found to be quite low $25.6 \%$ (at laboratory conditions), the collected data results in 158,754 germinable seeds per hectare. This number under ambient conditions gives an estimation of 1587.5 of 1-year old seedlings per ha to recruit the burnt area (based on the estimated possibility of $1 \%$ for a seed to produce seedling in the field), in the case of a fire event, if all other parameters remain favorable. Enright et al. [9], have estimated for other forest species that a production of about 100 seeds is needed to establish 1 adult plant. Thus, our data confirm the hypothesis that a period of 15-16 years interval between two fires is enough for a burnt pine forest to reach in such reproductive stage, able to secure its renewal if a fire occurs. The above number of germinable seeds, in combination with the observed regular distribution of trees with quite similar spatiotemporal dynamics [26], as well as the high percentage of trees bearing cones along the entire forest, lead us to reach the conclusion that forest renewal is expected to happen in the whole forest area. This should be greatly considered in fire protection and forest management plans, aiming at effectively protecting young post-fire forest stands, at least for a period of 15-16 years after a fire.

Seed dimensions were found to be similar with that of mature stands of the same species in the area [30], concluding that seed size does not depend on the tree age. On the contrary, Spanos et al. [14] reported higher values of seed weight (37.9 $\mathrm{mg}$ ) for 9-year-old P. brutia stands of Thasos island provenance. Seed germination was found to be very low 
(average $25.6 \%$ at laboratory conditions) compared to that found in other studies for seeds collected from mature P. brutia stands [14,31,32], (55.9\% to $83.2 \%$, depending mainly on the seed provenance); this smaller germination percentage may be due to the young age of the stands or due to the location of the studied forest, which is closed to the city of Thessaloniki. Ganatsas et al. [30], for the same P. brutia forest, also reported a low seed germination (average $24.0 \%$ ) and found that seed germination strongly depends on the distance from traffic road.

Investment in seed mass as the ratio of seed mass per cone to total cone weight reaches an average value of $6.51 \%$, and it was found to be significantly higher in the case of Filippio stands. Compared to other Mediterranean pines, this value is similar to that reported [13] for P. brutia in Samos (5\%-9\%), higher to that reported for P. halepensis $(3 \%-6 \%)$, but much lower than that of $P$. pinea $(30 \%-37 \%)$.

P. brutia, like other fire-adapted tree species, is a pioneering and obligate seeder that shows precocious reproduction, which in turn results in the development of a high canopy seed bank to be released after fire [33], securing in such a way the dominance of the species within its geographical distribution in a long-term basis. The regeneration mode is thus a major component of the forest stand dynamics model in Mediterranean-type fire-prone ecosystems [34].

\section{Conclusions}

Based on the analysis of the collected field data, it is confirmed the hypothesis that a period of 15-16 years interval between two fires is enough for a burnt serotinous pine (P. brutia) forest to reach its reproductive stage, able to secure its renewal if a fire occurs. This should be greatly considered in forest fire protection and management plans, which should aim to effectively protect young post-fire forests, at least to the age of 15-16 years.

Author Contributions: Conceptualization, P.G.; methodology, P.G. and M.T.; validation, M.T. and P.G.; formal analysis, P.G.; investigation, M.G. and A.G.; writing-original draft preparation, P.G.; writing-review and editing, M.T. All authors have read and agreed to the published version of the manuscript.

Funding: This research received no external funding.

Conflicts of Interest: The authors declare no conflict of interest.

\section{References}

1. Pérez-Sánchez, J.; Jimeno-Sáez, P.; Senent-Aparicio, J.; Díaz-Palmero, J.M.; Cabezas-Cerezo, J.D.D. Evolution of burned area in forest fires under climate change conditions in southern spain using ANN. Appl. Sci. 2019, 9, 4155. [CrossRef]

2. Singleton, M.P.; Thode, A.E.; Meador, A.J.S.; Iniguez, J.M. Increasing trends in high-severity fire in the southwestern USA from 1984 to 2015. For. Ecol. Manag. 2019, 433, 709-719. [CrossRef]

3. Stephens, S.L.; Collins, B.M.; Fettig, C.J.; Finney, M.A.; Hoffman, C.M.; Knapp, E.E.; North, M.P.; Safford, H.; Wayman, R.B. Drought, Tree Mortality, and Wildfire in Forests Adapted to Frequent Fire. BioScience 2018, 68, 77-88. [CrossRef]

4. Daskalakou, E.N.; Thanos, C.A. Aleppo Pine (Pinus halepensis) Postfire Regeneration: The Role of Canopy and Soil Seed Banks. Int. J. Wildland Fire 1996, 6, 59-66. [CrossRef]

5. Pausas, J.G.; Llovet, J.; Rodrigo, A.; Vallejo, R. Are wildfires a disaster in the Mediterranean basin?-A review. Int. J. Wildland Fire 2008, 17, 713-723. [CrossRef]

6. Tsitsoni, T.; Ganatsas, P.; Zagas, T.; Tsakaldimi, M. Dynamics of post-fire regeneration of Pinus brutia Ten. in an artificial forest ecosystem of northern Greece. Plant Ecol. 2004, 171, 165-174. [CrossRef]

7. Thanos, C.A.; Doussi, M.A. Postfire Regeneration of P. brutia Forests. In Ecology, Biogeography and Management of Pinus halepensis and P. brutia Forest Ecosystems in the Mediterranean Basin; Ne'eman, G., Trabaud, L., Eds.; Backhuys Publishers: Leiden, The Netherlands, 2000; pp. 291-301.

8. Ferrandis, P.; Las Heras, J.; Martínez-Sánchez, J.J.; Herranz, J.M. Influence of a low-intensity fire on a Pinus halepensis Mill. forest seed bank and its consequences on the early stages of plant succession. Isr. J. Plant Sci. 2001, 49, 105-114. [CrossRef]

9. Enright, N.J.; Lamont, B.B.; Marsula, R. Canopy seed bank dynamics and optimum fire regime for the highly serotinous shrub Banksia hookeriana. J. Ecol. 1996, 84, 9-17. [CrossRef]

10. Tapias, R.; Gil, L.; Fuentes-Utrilla, P.; José, A.; Pardos, J.A. Canopy seed banks in Mediterranean pines of south-eastern Spain: A comparison between Pinus halepensis Mill., P. pinaster Ait., P. nigra Arn. and P. pinea L. J. Ecol. 2001, 89, 629-638. [CrossRef] 
11. Boydak, M.; Dirik, H.; Calikoglu, M. Forest Stand Dynamic, Regeneration and Fire in Pinus brutia Ecosystems. In Biology and Silviculture of Turkish Red Pine (Pinus brutia Ten.); Istanbul Universitesi Orman Fakultesi: Ankara, Turkey, 2006.

12. Boydak, M. Silvicultural characteristics and natural regeneration of Pinus brutia Ten-A review. Plant Ecol. 2004, 171, 153-163. [CrossRef]

13. Thanos, C.A.; Marcou, S. Post-fire regeneration in Pinus brutia forest ecosystems of Samos island (Greece): 6 years after. Acta Oecol./Oecol. Plant. 1991, 12, 633-642.

14. Spanos, I.A.; Daskalakou, E.N.; Thanos, C.A. Post-fire, natural regeneration of Pinus brutia forests in Thasos island, Greece. Acta Oecol. 2000, 21, 2013-2020. [CrossRef]

15. Kavgaci, A.; Ortel, E.; Torres, I.; Safford, H. Early postfire vegetation recovery of Pinus brutia forests: Effects of fire severity, prefire stand age, and aspect. Turk. J. Agric. For. 2016, 40, 723-736. [CrossRef]

16. Spanos, I.A.; Radoglou, K.M.; Raftoyannis, Y. Site quality effects on post-fire regeneration of Pinus brutia forest on a Greek Island. Appl. Veget. Sci. 2001, 4, 229-236. [CrossRef]

17. Spanos, I.; Ganatsas, P.; Tsakaldimi, M. Evaluation of postfire restoration in suburban forest of Thessaloniki, northern Greece. Glob. NEST J. 2010, 12, 390-400.

18. Ganatsas, P.; Tsakaldimi, M.; Thanos, C. Seed and cone diversity and seed germination of Pinus pinea in Strofylia Site of the Natura 2000 Network. Biodivers. Conserv. 2008, 17, 2427-2439. [CrossRef]

19. ISTA (The International Seed Testing Association). International Rules for Seed Testing; ISTA: Bassersdorf, Switzerland, 2020; p. i-19-8(8).

20. Boydak, M.; Dirik, H.; Tilki, H.; Calikoglu, M. Effects of water stress on germination in six provenances of Pinus brutia seeds from different bioclimatic zones in Turkey. Turk. J. Agric. For. 2003, 27, 91-97.

21. Ganatsas, P.; Tsakaldimi, M.; Damianidis, C.; Stefanaki, A.; Kalapothareas, T.; Karydopoulos, T.; Papapavlou, K. Regeneration Ecology of the Rare Plant Species Verbascum dingleri: Implications for Species Conservation. Sustainability 2019, $11,3305$. [CrossRef]

22. Oliver, C.D.; Larson, B.C. Forest Stand Dynamics; McGraw-Hill: New York, NY, USA, 1990; 467p.

23. Sagnard, F.; Pichot, C.; Dreyfus, P.; Jordano, P.; Fady, B. Modelling seed dispersal to predict seedling recruitment: Recolonization dynamics in a plantation forest. Ecol. Model. 2007, 203, 464-474. [CrossRef]

24. Thanos, C.A.; Marcou, S.; Christodoulakis, D.; Yannitsaros, A. Early post-fire regeneration in Pinus brutia forest ecosystems of Samos island (Greece). Acta Oecol./Oecol. Plant. 1989, 10, 79-94.

25. Thanos, C.A.; Daskalakou, E.N.; Nikolaidou, S. Early post-fire regeneration of a Pinus halepensis forest on Mount Párnis, Greece. J. Veg. Sci. 1996, 7, 273-280. [CrossRef]

26. Nathan, R.; Ne'eman, G. Spatiotemporal dynamics of recruitment in Aleppo pine (Pinus halepensis Miller). Plant Ecol. 2004, 171, 123-137. [CrossRef]

27. De las Heras, J.; Moya, D.; Vega, J.A.; Daskalakou, E.; Vallejo, R.; Grigoriadis, N.; Tsitsoni, T.; Baeza, J.; Valdecantos, A.; Fernández, C.; et al. Post-Fire Management of Serotinous Pine Forests. In Post-Fire Management and Restoration of Southern European Forests, Managing Forest Ecosystems; Moreira, F., Arianoutsou, M., Corona, P., De las Heras, J., Eds.; Springer Science + Business Media B.V.: Dordrecht, The Netherlands, 2012; Volume 24. [CrossRef]

28. Ganatsas, P.; Thanasis, G. Pinus halepensis invasion in Pinus pinea habitat in Strofylia forest (Site of NATURA 2000 network), southern Greece. J. Nat. Conserv. 2010, 18, 106-117. [CrossRef]

29. Strid, A.; Tan, K. Flora Hellenica; Koeltz Scientific Books: Königstein, Germany, 1997; Volume 1.

30. Ganatsas, P.; Tsakaldimi, M.; Zachariadis, G. Effect of air traffic pollution on seed quality characteristics of Pinus brutia. Environ. Exp. Bot. 2011, 74, 157-161. [CrossRef]

31. Skordilis, A.; Thanos, C.A. Comparative Ecophysiology of Seed Germination Strategies in the Seven Pine Species Naturally Growing in Greece. In Basic and Applied Aspects of Seed Biology; Ellis, R.H., Black, M., Murdoch, A.J., Hong, T.D., Eds.; Kluwer Academic Publishers: Dordrecht, The Netherlands, 1997; pp. 623-632.

32. Paitaridou, D.; Ganatsas, P.; Sotiriou, K.; Varvarigos, G. Research on Seed Quality of Four Native Pine Species. In Proceedings of the 12th National Conference, Drama, Greece, 2-5 October 2005; Hellenic Forestry Society: Thessaloniki, Greece, 2006; pp. 151-158, (Greek with English Summary).

33. González-De Vega, S.; de las Heras, J.; Moya, D. Post-Fire Regeneration and Diversity Response to Burn Severity in Pinus halepensis Mill. Forests 2018, 9, 299. [CrossRef]

34. Tavsanoglu, C.; Gurkan, K. Long-term post-fire dynamics of co-occurring woody species in Pinus brutia forests: The role of regeneration mode. Plant Ecol. 2014, 215, 355-365. [CrossRef] 